\title{
Draft Guidance: Response, Restoration, and Recovery Checklist for Biologically Contaminated Facilities
}

S. Mancieri, E. Raber, T. Carlsen, C. Fish, D. MacQueen, W. Hoppes, T. Bunt, A. Intrepido, W. Wilson, S. James, J. Richards, J. Dzenitis, and K. Folks 


\section{Disclaimer}

This document was prepared as an account of work sponsored by an agency of the United States Government. Neither the United States Government nor the University of California nor any of their employees, makes any warranty, express or implied, or assumes any legal liability or responsibility for the accuracy, completeness, or usefulness of any information, apparatus, product, or process disclosed, or represents that its use would not infringe privately owned rights. Reference herein to any specific commercial product, process, or service by trade name, trademark, manufacturer, or otherwise, does not necessarily constitute or imply its endorsement, recommendation, or favoring by the United States Government or the University of California. The views and opinions of authors expressed herein do not necessarily state or reflect those of the United States Government or the University of California, and shall not be used for advertising or product endorsement purposes.

This report has been reproduced directly from the best available copy.

This work was performed under the auspices of the U.S. Department of Energy by University of California, Lawrence Livermore National Laboratory under Contract W-7405-Eng-48. 


\section{Draft Guidance: Response, Restoration, and Recovery Checklist for Biologically Contaminated Facilities}

S. Mancieri, E. Raber, T. Carlsen, C. Fish, D. MacQueen, W. Hoppes, T. Bunt, A. Intrepido, W. Wilson, S. James, J. Richards, J. Dzenitis, and K. Folks

August 14, 2006 


\section{Table of Contents}

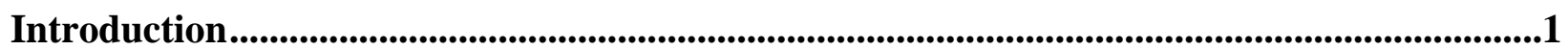

Checklist for Facility Response, Restoration, and Recovery .................................................3

Recommendations for Facility Preparedness .................................................................................7

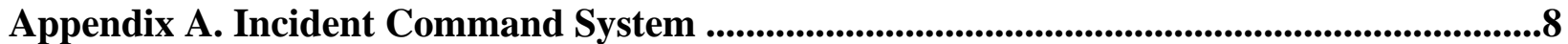

\section{List of Figures}

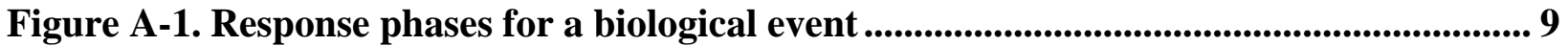

Figure A-2. Organizational structure of the consequence management phase.................... 10

Figure A-3. Components of the UC, TWG, and ECC during consequence management.... 11 


\section{Draft Guidance: Response, Restoration, and Recovery Checklist for Biologically Contaminated Facilities}

\section{Introduction}

The Checklist for Facility Response, Restoration, and Recovery presented in this document is principally focused on the Consequence Management Phase (see Figure A-1; LLNL 2006) of a biothreat agent (i.e., Bacillus anthracis) release at a large facility, such as an airport or subway. Information in this document conforms to the National Response Plan (NRP) (DHS 2004) and the National Incident Management System (NIMS 2004). Under these two guidance documents, the personnel responsible for managing biological response and recovery efforts - that is, the decision-makers - are members of an Incident Command (IC), which is likely to transition to a Unified Command (UC) in the event of a biological warfare agent attack. A UC is used when more than one agency has incident jurisdiction or when incidents cross political jurisdictions. The location for primary, tactical-level command and management is referred to as the Incident Command Post (ICP), as described in the NRP. Thus, regardless of whether an IC or an UC is used, the responsible entities are located at an ICP. Agencies work together through designated members of the UC to establish their designated Incident Commanders at a single ICP and to establish a common set of objectives and strategies and a single Incident Action Plan.

Initially during the Crisis Management Phase (see Figure A-1), the Incident Commander is likely to be the Chief of the fire department that serves the affected facility. As life-safety issues are resolved and the Crisis Management Phase shifts to the Consequence Management Phase, the work of characterization, decontamination, and facility clearance begins. There will likely be a coincident transition in organizational structure as well, and new restoration-focused groups, units, and personnel will be added as restoration needs are anticipated. Depending on the specific facility and type of incident, the responsible individual (Incident Commander or Unified Commander) within the UC during the Consequence Management Phase could be the Facility Manager, the Facility Emergency Operations Manager, or their designee.

In an incident involving large-scale biological contamination, the Governor of the state would typically request, and the President of the United States would likely declare, an emergency under the Stafford Act (1974; amended 2002). The Secretary of Homeland Security would likely determine that the event is an Incident of National Significance on the basis of criteria established in Homeland Security Presidential Directive 5 (HSPD-5), "Management of Domestic Incidents.” Incidents of National Significance are those high-impact events that require a coordinated and effective response by an appropriate combination of Federal, state, local, tribal, private-sector, and nongovernmental entities to save lives, minimize damage, and provide the basis for long-term community recovery and mitigation activities.

If facility authorities request outside assistance, or if an emergency is declared under the Stafford Act, then other members of the UC could include local and state agencies as well as Federal agencies, such as the Federal Emergency Management Agency (FEMA) and the U.S. 
Environmental Protection Agency (USEPA). If an Incident of National Significance is declared, a Principal Federal Official will be appointed by the Department of Homeland Security (DHS) to facilitate Federal support to the UC structure.

The following Checklist for Facility Response, Restoration, and Recovery presents the critical steps that would be taken by organizations involved in responding to a biological incident. It is intended for use by key decision-makers in the event that an incident occurs and steps must be taken immediately and systematically. The organizations would follow the Incident Command System (ICS). See Appendix A for more information on the ICS and how the responsible personnel identified in the checklist map into the consequence management organizational structure. The Notification and First-Response Phases are cursorily addressed in the checklist, whereas the main focus is on consequence management actions. The order of actions is generally sequential. However, depending on the specifics of an event and how the response is implemented, actions may be reordered. For example, preparing a Remediation Action Plan (RAP) is identified in the checklist as a critical step of the Remediation Phase. However, it is likely that preparation of the RAP would begin before completing all actions identified in the Characterization Phase.

In addition to the actions recommended in the checklist, any emergency response conducted at a major metropolitan facility should comply with notification and response procedures established by the facility, as well as applicable procedures established by the jurisdictional responding agencies.

\section{Notes and References}

DHS (December 2004), Department of Homeland Security, National Response Plan, available at <http://www.dhs.gov/dhspublic/interapp/editorial/editorial_0566.xml>.

LLNL (2006), Lawrence Livermore National Laboratory, Restoration Plan for Major International Airports After a Bioterrorist Attack, Lawrence Livermore National Laboratory, Livermore, CA, UCRL-TR-210178-DRAFT Rev. 2; to be issued as a joint Department of Homeland Security and U.S. Environmental Protection Department document.

NIMS (March 1, 2004), National Incident Management System, document available from FEMA at 1-800-480-2520, Option 4, ask for FEMA 501.

Robert T. Stafford Disaster Relief and Emergency Assistance Act, 93 Pub. L. No. 288, 88 Stat 143 (1974) [codified as amended at 42 U.S.C. $\S \S 5121-5206$ and scattered sections of 12 U.S.C., 16 U.S.C., 20 U.S.C., 26 U.S.C., and 38 U.S.C. (2002)]. 


\section{Checklist for Facility Response, Restoration, and Recovery}

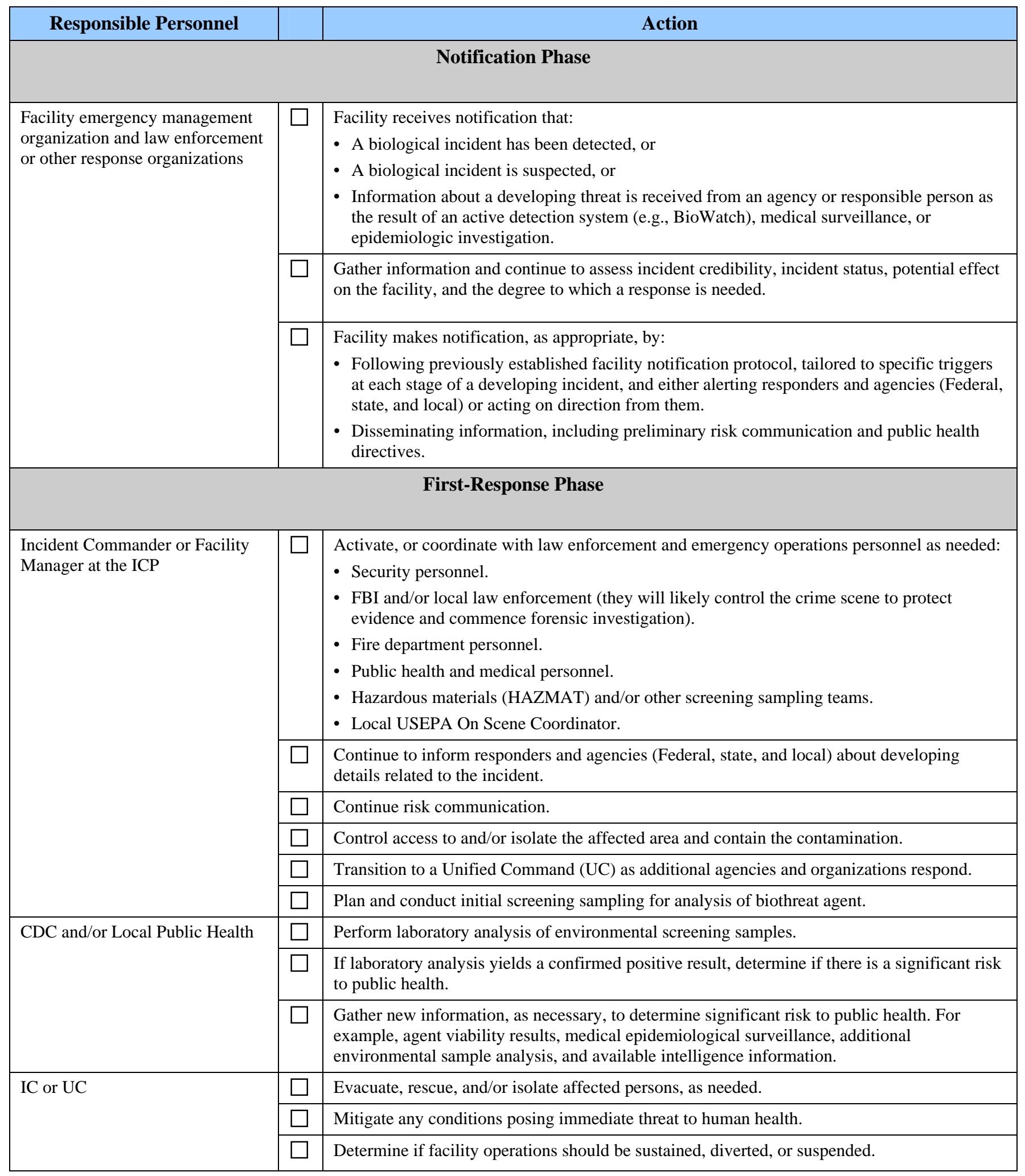




\section{Checklist continued.}

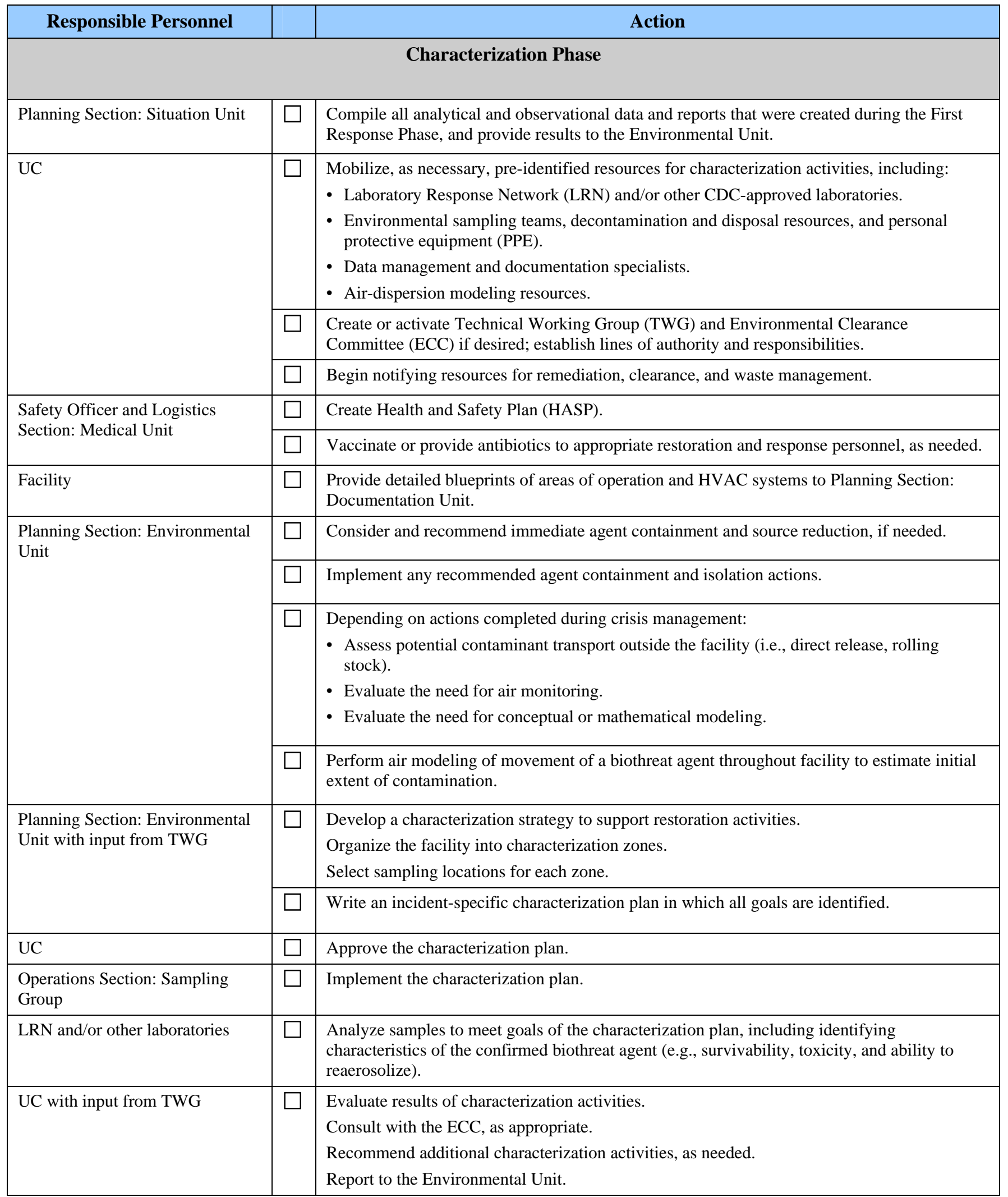




\section{Checklist continued.}

\begin{tabular}{|c|c|c|}
\hline Responsible Personnel & & Action \\
\hline \multicolumn{3}{|r|}{ Remediation Phase } \\
\hline $\begin{array}{l}\text { Planning Section: Environmental } \\
\text { Unit with input from TWG }\end{array}$ & $\square$ & $\begin{array}{l}\text { Develop cleanup goals and measurable cleanup performance criteria, as appropriate, based on } \\
\text { characterization results with input from the ECC. }\end{array}$ \\
\hline UC & $\square$ & Approve overall cleanup goals. \\
\hline \multirow[t]{4}{*}{$\begin{array}{l}\text { Planning Section: Environmental } \\
\text { Unit with input from TWG }\end{array}$} & $\square$ & $\begin{array}{l}\text { Develop the decontamination strategy, including assessment of potential environmental } \\
\text { impacts of remediation. }\end{array}$ \\
\hline & $\square$ & $\begin{array}{l}\text { Prepare the Remediation Action Plan (RAP), including: } \\
\text { - Areas to decontaminate and types of surfaces involved. } \\
\text { - Materials and structures to decontaminate in place or remove. } \\
\text { - What decontamination technologies to use (e.g., reagent and delivery system). } \\
\text { - Appropriate process parameters and analytical techniques. }\end{array}$ \\
\hline & $\square$ & Include Ambient Air Monitoring Plan (AAMP) in RAP if fumigation is used. \\
\hline & $\square$ & $\begin{array}{l}\text { Prepare Clearance Sampling and Analysis Plan (SAP), including: } \\
\text { - Clearance zones. } \\
\text { - Sampling approach(es) for each zone (e.g., targeted, biased, and random or statistical } \\
\text { sampling). } \\
\text { - Aggressive air sampling, as necessary. }\end{array}$ \\
\hline \multirow{2}{*}{$\begin{array}{l}\text { Operations Section: } \\
\text { Decontamination Group }\end{array}$} & $\square$ & Perform source reduction. \\
\hline & $\square$ & Review draft RAP and SAP. \\
\hline \multirow[t]{2}{*}{ UC } & $\square$ & Approve the RAP and SAP with input from the ECC. \\
\hline & $\square$ & $\begin{array}{l}\text { Submit RAP and SAP to USEPA to obtain a crisis exemption if using an unregistered product } \\
\text { for decontamination (i.e., one that is not an EPA-approved sterilant or pesticide). }\end{array}$ \\
\hline Facility Safety Officer & $\square$ & $\begin{array}{l}\text { If fumigation is selected, develop an Emergency Response Plan to address potential } \\
\text { uncontrolled fumigation releases (e.g., from explosion, fire, or hurricane). }\end{array}$ \\
\hline $\begin{array}{l}\text { Operations Section: } \\
\text { Decontamination and Sampling } \\
\text { Groups }\end{array}$ & $\square$ & Perform all site preparations as specified in the RAP. \\
\hline $\begin{array}{l}\text { Operations Section: } \\
\text { Decontamination Group }\end{array}$ & $\square$ & Conduct decontamination. \\
\hline UC with input from TWG & $\square$ & $\begin{array}{l}\text { Evaluate whether decontamination process criteria are met. Consult with ECC as appropriate. } \\
\text { - Fumigation (e.g., biological indicators, concentration, temperature) } \\
\text { - Surface decontamination (e.g., limited surface sampling, contact time, pH) } \\
\text { Recommend additional decontamination activities, as necessary. }\end{array}$ \\
\hline
\end{tabular}




\section{Checklist continued.}

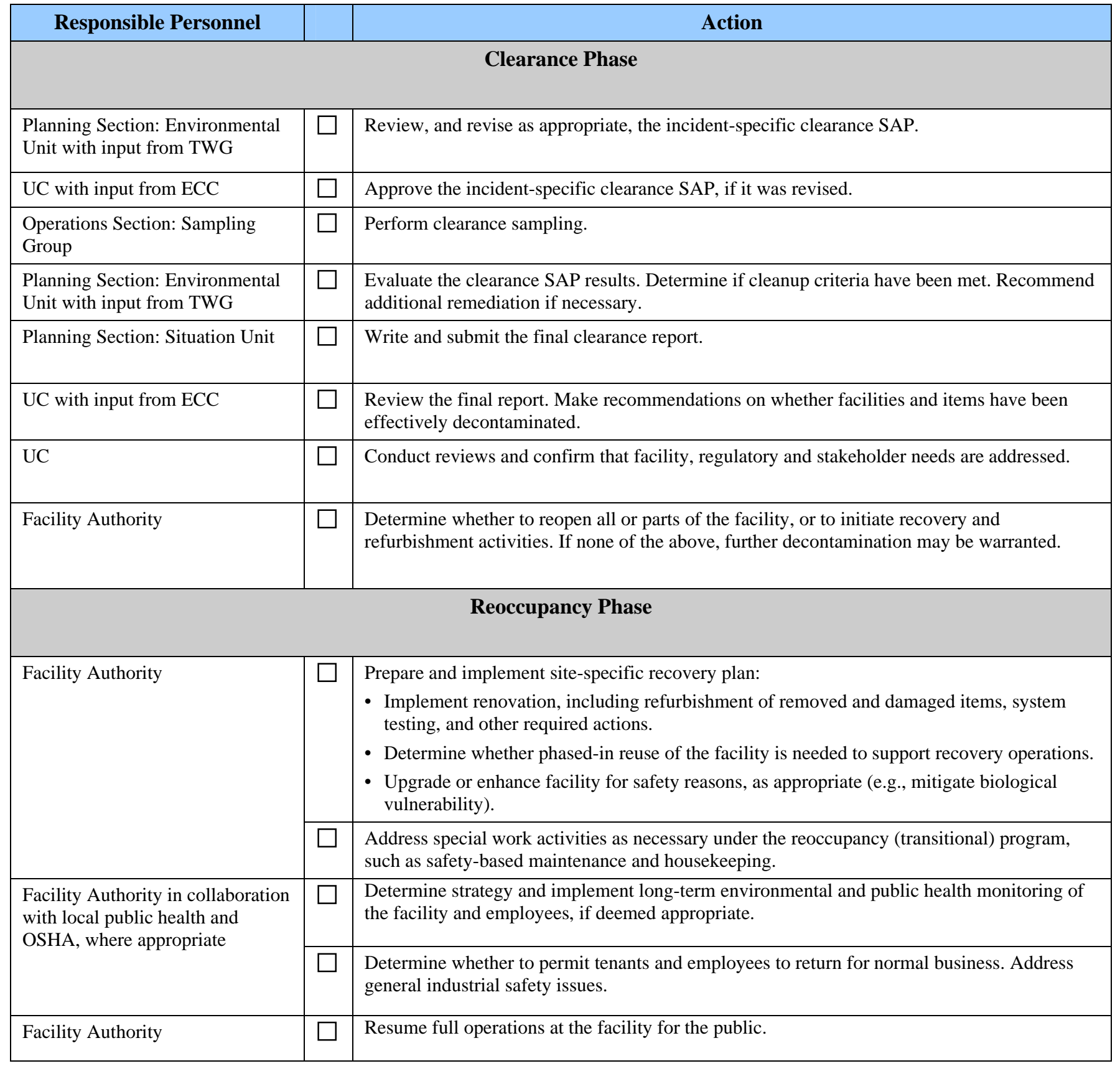




\section{Recommendations for Facility Preparedness}

The following list identifies preparedness activities a facility should conduct to expedite biological restoration. Activities are listed under the response phase with which they are most closely associated.

\section{Initial Notification-Related Preparation}

- Incorporate specific biological response plans into the facility's emergency response plan, as appropriate.

- Develop a notification protocol for all facility personnel, responders, and agencies (Federal, state, and local) tailored to each stage of a developing incident.

\section{First Response-Related Preparation}

- Develop a policy specifying the criteria for facility closure or suspension of operations after a biothreat agent attack. The policy should incorporate public health strategies and management of employees, rolling stock, and patrons.

- Identify members of a Unified Command (UC), convene the UC, and review the facility's restoration plan.

- Conduct training exercises with likely command personnel, including responder and agency representatives.

\section{Characterization-Related Preparation}

- Identify members of a Technical Working Group (TWG), as appropriate. Members are drawn from the Centers for Disease Control and Prevention (CDC), U.S. Environmental Protection Agency (USEPA), local public health, sampling contractors, and analytical laboratories. The TWG should review the facility's restoration plan.

- Identify characterization resources, such as sampling contractors and analytical laboratories.

- Identify potential sampling, characterization, fumigation, and decontamination zones within the facility.

- Identify sampling units (which may consist of surfaces, items, or sets of items) to be sampled.

- Identify areas at the facility that can be used or cleared for staging and storing waste materials.

- Create and maintain an up-to-date library of key facility architectural and mechanical drawings including heating, ventilation and air conditioning (HVAC) operating parameters.

- Update building vulnerability assessments periodically, and correct any deficiencies.

- Create a new, or review and revise an existing, Health and Safety Plan (HASP).

\section{Remediation-Related Preparation}

- Identify in-house equipment that could be used or upgraded for remediation activities.

- Select staging areas or warehouses for equipment and supplies.

- Predetermine disposal and restoration options for potentially contaminated materials.

- Determine likely decontamination method(s).

- Determine types of decontamination supplies to store.

- Select and retain contractors for the decontamination team.

- Identify staging and storage areas for waste.

- Initiate discussions with local waste-disposal facilities and wastewater treatment facilities.

- Discuss waste-disposal issues with State solid waste management authority.

\section{Clearance-Related Preparation}

- Identify members of an Environmental Clearance Committee (ECC), as appropriate. ECC members should review the facility's restoration plan.

\section{Reoccupancy-Related Preparation}

- Develop a Hazard Communication Plan, including written examples that would be used to inform employees and the general public about possible risks associated with reoccupancy. 


\section{Appendix A. Incident Command System}

The Incident Command System (ICS) is a standardized, flexible, on-scene, emergency management construct specifically designated to provide for the adoption of an integrated organizational structure that reflects the complexity and demands of single or multiple incidents, without being hindered by jurisdictional boundaries. It includes the combination of facilities, equipment, personnel, procedures, and communications operating within a common organizational structure and is designed to aid in managing resources during an emergency response, such as an incident involving a biothreat agent. It is critical that the ICS structure remain flexible and adaptable. It can be resized and restructured as the incident unfolds, adding or disbanding various groups, as dictated by the incident. The consequence management organization structure shown in Figure A-2 shows typical relationships among ICS organizations involved in consequence management of a biological contamination incident.

Formation of a Technical Working Group (TWG) early in an incident is strongly recommended. This group of technical specialists helps to plan restoration operations and provides advice to the Incident Commander or Unified Commander, staff, and contractors.

Formation of an Environmental Clearance Committee (ECC) is also strongly recommended. This group acts as an independent body to review cleanup thresholds and the effectiveness of remediation activities, and it recommends whether a facility should be opened for reoccupancy.

Figure A-3 identifies some of the specialty areas that would be required of personnel who staff the Unified Command, TWG, and ECC or the organizations that could provide representatives for each group. Technical roles played by members of the TWG and ECC are varied and challenging. For an incident involving a biological warfare agent, qualifications would include medical or restoration experience related to biological contamination. 


\begin{tabular}{|c|c|c|c|c|c|}
\hline \multirow{2}{*}{\multicolumn{2}{|c|}{$\begin{array}{c}\text { CRISIS MANAGEMENT } \\
\text { RESPONSE } \\
\text { ACTIVITIES }\end{array}$}} & \multicolumn{4}{|c|}{ CONSEQUENCE MANAGEMENT } \\
\hline & & \multicolumn{3}{|c|}{$\begin{array}{l}\text { RESTORATION } \\
\text { ACTIVITIES }\end{array}$} & \multirow{2}{*}{\begin{tabular}{|c}
$\begin{array}{l}\text { RECOVERY } \\
\text { ACTIVITIES }\end{array}$ \\
REOCCUPANCY
\end{tabular}} \\
\hline NOTIFICATION & FIRST RESPONSE & CHARACTERIZATION & $\begin{array}{l}\text { REMEDIATION/ } \\
\text { CLEANUP }\end{array}$ & CLEARANCE & \\
\hline 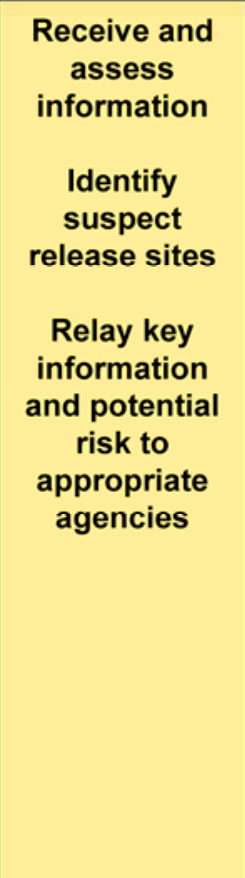 & $\begin{array}{c}\text { HAZMAT and } \\
\text { emergency } \\
\text { actions } \\
\text { Forensic } \\
\text { investigation } \\
\text { Public } \\
\text { health actions } \\
\text { Screening } \\
\text { sampling } \\
\text { Determine } \\
\text { agent type, } \\
\text { concentration, } \\
\text { and viability } \\
\text { Risk } \\
\text { communication }\end{array}$ & 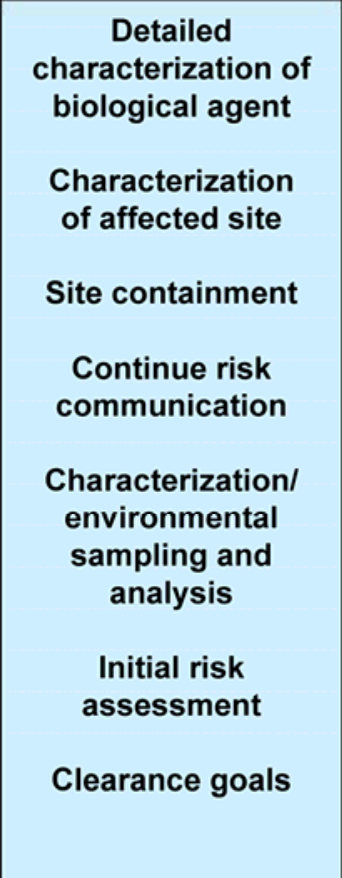 & \begin{tabular}{|c}
$\begin{array}{c}\text { Decontamination } \\
\text { strategy }\end{array}$ \\
Remediation \\
action plan \\
Worker \\
health \& safety \\
Site \\
preparation \\
Source \\
reduction \\
Waste disposal \\
Decontamination \\
of sites \\
and/or items \\
Decontamination \\
verification
\end{tabular} & $\begin{array}{c}\text { Clearance } \\
\text { sampling } \\
\text { and } \\
\text { analysis } \\
\text { Clearance } \\
\text { decision }\end{array}$ & $\begin{array}{c}\text { Renovation } \\
\text { Longer-term } \\
\text { environmental } \\
\text { and } \\
\text { public health } \\
\text { monitoring } \\
\text { Reoccupation } \\
\text { decision }\end{array}$ \\
\hline
\end{tabular}

Figure A-1. Response phases for a biological event. The content of this illustration was developed with interagency cooperation (LLNL 2006). 
Figure A-2. Organizational structure of the consequence management phase of a biological attack. See Figure A-3 for additional detail.

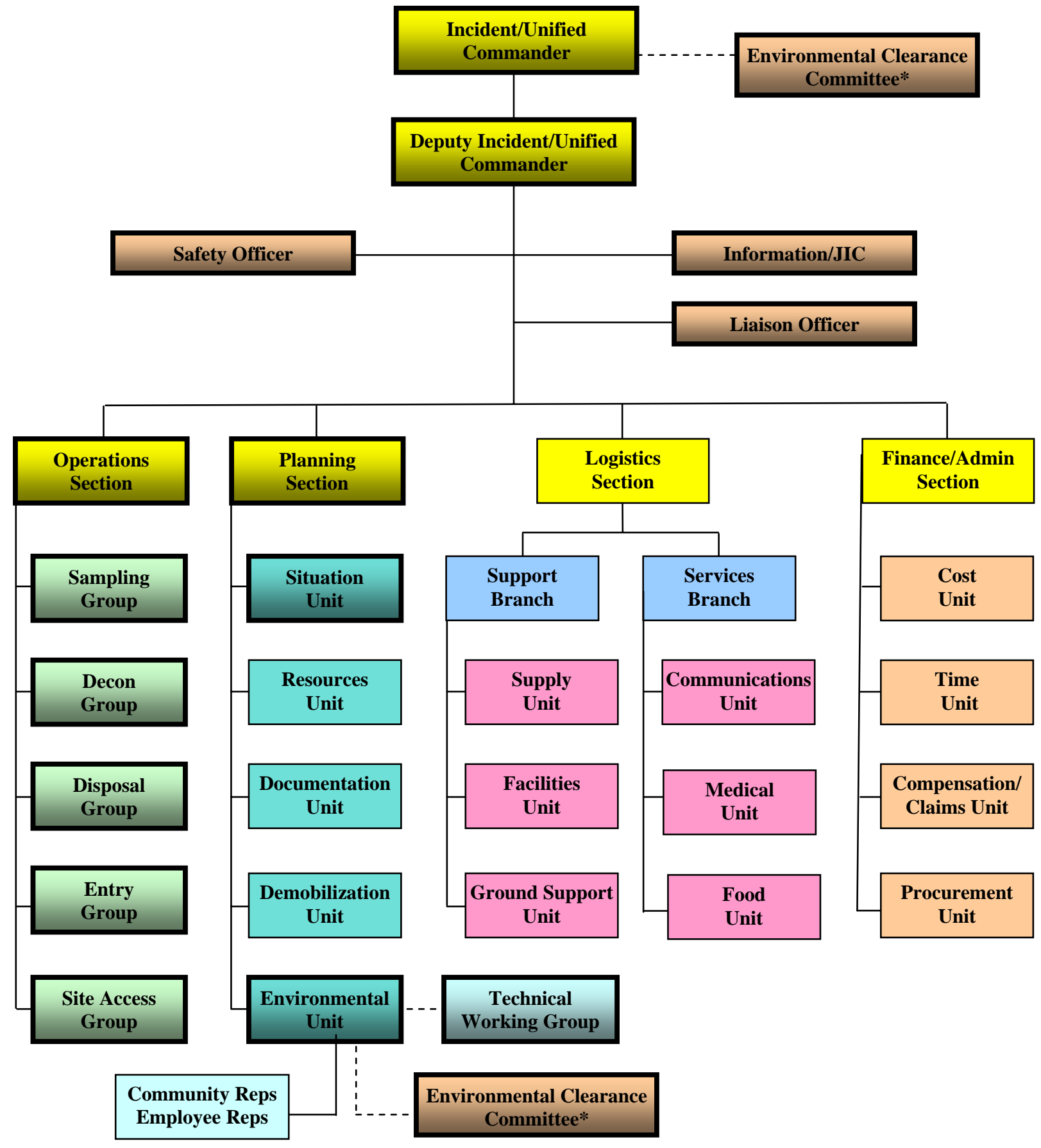

* At the discretion of the UC, the ECC may either report directly to the UC or function under the direction of the Environmental Unit Leader. 
Unified Command

- Facility representative

- State and local public health

- Emergency Management Agency

- EPA On-Scene Coordinator

- City representative

\begin{tabular}{|l|}
\hline \multicolumn{1}{|c|}{ Technical Working Group } \\
- Areas of Required Expertise \\
- Microbiology \\
- Sterilization science \\
- Waste disposal \\
- Ambient air monitoring \\
- Environmental sampling \\
- Chemical engineering \\
- Representatives from \\
- Facility \\
- EPA \\
- CDC, NIOSH \\
- State and local public health/analytical \\
laboratories \\
- Other affected public health agencies \\
- OSHA \\
- Private sector \\
- Universities
\end{tabular}

\begin{tabular}{|l|}
\hline \multicolumn{1}{|c|}{ Environmental Clearance Committee } \\
- Areas of Required Expertise \\
- Microbiology \\
- Epidemiology \\
- Sterilization science \\
- Environmental sampling \\
- Risk assessment \\
- Industrial hygiene \\
- Representatives from \\
- State and local health department (Chair) \\
- EPA with ECC experience (Co-Chair) \\
- Local health officer \\
- CDC, NIOSH \\
- CDC, NCID \\
- OSHA \\
- Stakeholder representatives (ex officio) \\
\hline
\end{tabular}

Figure A-3. Components of the UC, TWG, and ECC during consequence management. 
University of California

Lawrence Livermore National Laboratory

Technical Information Department

Livermore, CA 94551

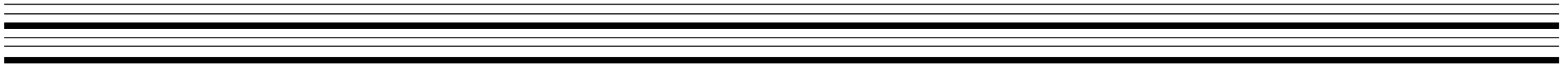

